\title{
Interactions between Stromal Cell-derived Keratinocyte Growth Factor and Epithelial Transforming Growth Factor in Immune-mediated Crypt Cell Hyperplasia
}

\author{
Mona Bajaj-Elliott, ${ }^{\star}$ Richard Poulsom, ${ }^{\S}$ Sylvia L.F. Pender, ${ }^{\star}$ Neville C. Wathen, ${ }^{\ddagger}$ and Thomas T. MacDonald ${ }^{\star}$ \\ $*$ Department of Paediatric Gastroenterology and ${ }^{\ddagger}$ Department of Obstetrics and Gynaecology, St. Bartholomew's and the Royal London \\ School of Medicine and Dentistry, London, United Kingdom; and ${ }^{\S}$ Histopathology Unit, Imperial Cancer Research Fund Laboratories, \\ London, United Kingdom
}

\begin{abstract}
Immune reactions in the gut are associated with increased epithelial cell proliferation. Here we have studied the role of keratinocyte growth factor (KGF; FGF7) and transforming growth factor- $\alpha$ (TGF- $\alpha)$ in the epithelial cell hyperplasia seen in explants of fetal human small intestine after activation of lamina propria T cells with the superantigen Staphylococcus aureus enterotoxin B (SEB). After the addition of SEB to the explants there is a 10-fold increase in KGF mRNA by $72 \mathrm{~h}$ of culture. KGF transcripts were abundant in the lamina propria using in situ hybridization and the culture supernatants contained elevated amounts of KGF protein. SEB had no direct effect on KGF mRNA and protein production by cultured lamina propria mesenchymal cells, but both were upregulated by TNF- $\alpha$. Accompanying the increase in KGF there was also an increase in TGF- $\alpha$ precursor proteins in the culture supernatants and the phosphorylated form of the EGFR receptor was also detected in the tissue. Increased TGF- $\alpha$ precursor proteins were also detected in the supernatants of control explants stimulated with KGF alone. The direct addition of KGF and TGF- $\alpha$ enhanced epithelial cell proliferation and antibodies against KGF and TGF- $\alpha$ partially inhibited SEB-induced crypt hyperplasia. These results suggest molecular cross-talk between the KGF/KGFR and the TGF- $\alpha /$ EGFR in immunemediated crypt cell hyperplasia. (J. Clin. Invest. 1998. 102: 1473-1480.) Key words: inflammation - wound healing • growth factor • epithelial cell proliferation • tissue repair
\end{abstract}

\section{Introduction}

Intestinal inflammation is associated with increased epithelial cell proliferation and hypertrophy of the crypts of Lieberkühn. When the inflammation is part of protective immunity, increased epithelial proliferation and crypt hypertrophy can be seen as a mechanism to replace infected or damaged enterocytes, to provide cells to cover areas of enterocyte loss, and to reduce mucosal surface area. Pari passu there is loss of intestinal function since absorptive surface area and brush border di-

Address correspondence to Thomas T. MacDonald, Dept. of Paediatric Gastroenterology, St. Bartholomew's Hospital, London EC1A 7BE, United Kingdom. Phone: 44-171-601-8160; FAX: 44-171-6005901; E-mail: T.T.MacDonald@mds.qmw.ac.uk

Received for publication 2 February 1998 and accepted in revised form 19 August 1998.

J. Clin. Invest.

(C) The American Society for Clinical Investigation, Inc. 0021-9738/98/10/1473/08 \$2.00

Volume 102, Number 8, October 1998, 1473-1480

http://www.jci.org gestive enzymes are decreased. In chronic diseases of the gut, however, as in the inappropriate response to wheat in celiac disease and the idiopathic lesions in inflammatory bowel disease, long-term inflammation leads to chronically elevated epithelial cell proliferation and compromised absorptive function. The functional relationship between inflammatory cells and epithelial renewal in the gut is not well understood.

There are at least two possible ways in which inflammatory cells and their products could influence intestinal epithelial cell renewal. First, cytokines could have a direct mitogenic effect on epithelial cells. There is in vitro evidence that cytokines can enhance the proliferation of epithelial cell lines (1-4) but there is also good evidence that IFN- $\gamma$, local concentrations of which are elevated in a number of gut diseases, is cytostatic (5). In vivo, using murine graft-versus-host disease as a model, Mowat and co-workers have shown that inhibition of nitric oxide, IL-1, IL-4, or IFN- $\gamma$ prevents the intestinal crypt hyperplasia seen in these conditions (6-8). The same group has also shown that direct injection of IFN- $\gamma$ or TNF- $\alpha$ in normal mice causes crypt hyperplasia (9). Likewise, mice bearing IFN- $\gamma$-secreting tumors develop hyperplastic crypts (10).

The second way in which inflammatory cells and cytokines could alter epithelial proliferation is indirect, i.e., by modulating other resident cells (mesenchymal cells [MSC] and muscle cells) in the lamina propria, which may affect the homeostatic control of epithelial cell proliferation. Several growth factors are known to work in a paracrine/juxtacrine fashion in both promoting and inhibiting gut epithelial cell proliferation. For example, TGF- $\beta$ inhibits epithelial proliferation (11), whereas glucagon-like peptide 2, IGF-1, and EGF enhance epithelial proliferation (12-14). Overall, however, whether crypt hyperplasia is mediated directly by the products of immune cells or indirectly is not known.

Keratinocyte growth factor (KGF; fibroblast growth factor-7, FGF-7 $)^{1}$ is a member of the FGF family of growth factors, is secreted by stromal cells, and is thought to be important in control of epithelial proliferation in the lung and skin, especially after injury (15-18). Expression of KGF and its receptor has been detected throughout the gastrointestinal tract, suggesting KGF to be an endogenous mediator of growth and differentiation in this tissue (19). Recent studies have also shown marked upregulation of KGF mRNA expression in inflammatory bowel disease, especially in ulcerative colitis (20-22). TGF- $\alpha$, a member of the EGF family of growth factors, is produced by epithelial cells in vivo and can modulate epithelial function both in vitro and in vivo (23-25). Recent studies by Dignass and colleagues have shown both KGF and TGF- $\alpha$ to have modest effects on epithelial cell proliferation in several epithelial cell lines $(26,27)$.

1. Abbreviations used in this paper: EGFR, EGF receptor; FGF, fibroblast growth factor; KGF, keratinocyte growth factor; MSC, mesenchymal cell; SEB, Staphylococcus aureus enterotoxin B. 
To determine if KGF and TGF- $\alpha$ have a functional role in promoting epithelial cell renewal during local immune reactions, we have used an ex vivo model of $\mathrm{T}$ cell activation in explants of fetal human intestine. When the bacterial superantigen Staphylococcus aureus enterotoxin B (SEB) is added to explants in culture, it diffuses through the cut edges of the tissue and activates the resident lamina propria $\mathrm{V} \beta 3+$ cells in situ. The T cell response is of a Th1 type and there is increased production of IFN- $\gamma$ and TNF- $\alpha$ (28). Within $3 \mathrm{~d}$ there is a large increase in dividing crypt epithelial cells, which can be almost completely inhibited by the $\mathrm{T}$ cell immunosuppressive agent FK506, showing that SEB is not having a direct effect on epithelial renewal. In this study we have attempted to identify the role of KGF and TGF- $\alpha$ in the crypt hyperplasia seen after $\mathrm{T}$ cell activation. Our studies show marked upregulation of both growth factors on $\mathrm{T}$ cell stimulation suggesting both KGFR and EGFR signaling pathways play a role in epithelial renewal. Further, KGF alone can upregulate the amount of TGF- $\alpha$ precursor proteins, indicative of cross-talk between the two receptor systems.

\section{Methods}

Fetal gut organ culture. Ethical approval was received from the City and Hackney Health Authority.

Human fetal small intestine was obtained $2 \mathrm{~h}$ after surgical termination from the Medical Research Council Tissue Bank at Hammersmith Hospital, London and/or the Homerton Hospital, London. All tissue samples in this study were of 15-16-wk gestation. 20 explants $\left(1-2 \mathrm{~mm}^{2}\right)$ were cultured in $7 \mathrm{ml}$ Autrups serum-free media (29), with the omission of hydrocortisone at $37^{\circ} \mathrm{C}$. Stimulation of resident $\mathrm{T}$ cells in the explants was achieved by addition of SEB $(10 \mu \mathrm{g} / \mathrm{ml}$; Sigma, Poole, Dorset, UK).

Polyclonal goat anti-human KGF, TGF- $\alpha$, and IGF-1 antibodies $(10 \mu \mathrm{g} / \mathrm{ml} ; \mathrm{R} \& D$ Systems, Abingdon, UK) were added to control and SEB-stimulated explant cultures. A goat anti-mouse IgG (Harlan Sera-Lab, Loughborough, UK) was used as a control.

$R N A$ extraction and quantitative RT-PCR. To facilitate quantitation of KGF mRNA by PCR, we constructed a plasmid to produce a standard RNA molecule. Details of plasmid construction and general methodology have been described elsewhere (22). In brief, using the same primer set, RT-PCR of the standard RNA molecule yields a PCR product of $440 \mathrm{bp}$, whereas the target tissue yields a 266-bp fragment, the difference in size allowing quantitation of the KGF mRNA transcripts as follows. PCR products were analyzed on $1 \%$ agarose gels and the bands were visualized by ethidium bromide staining. Band intensities were quantified by densitometry (Seescan 1D gel analysis package v 1.00; Seescan, Cambridge, UK). The ratio of standard to target PCR products was plotted against the number of standard RNA transcripts in the reaction on a double logarithmic scale. In this way, the point of the starting amount of cellular target transcripts can be determined. The sensitivity of this technique enables the detection of $<1,000 \mathrm{KGF}$ mRNA transcripts/ $\mu \mathrm{g}$ of total RNA.

Stimulation of fetal mucosal MSC. The isolation and characterization of fetal small intestine mucosal MSC has been described in detail elsewhere (30). In brief, the small intestine was dissected and the mucosa scraped gently with a scalpel. The scrapings were gently broken by repetitive pipetting and the resultant cell suspension was cultured and maintained in MEM and 10\% FCS (Life Technologies, Paisley, UK). Nonadherent cells were removed on day 2 and the media were changed every $3-4 \mathrm{~d}$. Cells at passage 4 and beyond were used in this study, when epithelial cells and HLA-DR-positive cells were minimal. Each batch of cells was characterized by immunocytochemistry before use $(30)$. MSC $\left(5 \times 10^{5}\right)$ cells were seeded into 25 $\mathrm{cm}^{2}$ area culture flasks until confluent. The cells were cultured for a further $24 \mathrm{~h}$ in serum-free $(0.5 \%$ FCS $)$ media before the addition of TNF- $\alpha(5 \mathrm{ng} / \mathrm{ml})$, IFN- $\gamma(300 \mathrm{U} / \mathrm{ml})$, or SEB $(10 \mu \mathrm{g} / \mathrm{ml})$ for $48 \mathrm{~h}$. Flasks cocultured with IFN- $\gamma$ and SEB were initially cultured with IFN- $\gamma$ for $24 \mathrm{~h}$ with subsequent addition of SEB for $48 \mathrm{~h}$. The cytokines were from R\&D Systems.

Immunocytochemistry. The explants were carefully removed after culture and placed on top of each other on a piece of filter paper to absorb excess moisture. Explants were then covered with OCT mountant (H \& E; Histological Equipment Ltd., Nottingham, UK) on cork, snap-frozen immediately in liquid $\mathrm{N}_{2}$-cooled 2-methyl butane (Aldrich Chemical Co. Ltd., Poole, Dorset, UK), and stored at $-70^{\circ} \mathrm{C}$. $6-\mu \mathrm{m}$ frozen sections were stained for proliferating cells using the antibody Ki-67 (Dako Ltd., High Wycombe, UK) by the indirect peroxidase method (31). Quantitation of dividing cells was carried out as described previously (32).

Western blotting. Large scale explant cultures were set up to increase protein yield. 60 explants were cultured in $21 \mathrm{ml}$ of Autrups media in the presence of $10 \mu \mathrm{g} / \mathrm{ml}$ of SEB. After $72 \mathrm{~h}$, the supernatants were collected and spun $(1,200 \mathrm{~g}, 10 \mathrm{~min})$ to remove cellular debris. The amount of protein in the supernatants was determined using the Bio-Rad protein (Bradford) assay. Supernatants (control and SEB-stimulated) containing $250 \mu \mathrm{g}$ total protein were incubated with $50 \mu \mathrm{l}$ of heparin-Sepharose beads (Sigma) and gently mixed for $2 \mathrm{~h}$ at room temperature. The beads were washed directly in $2 \times$ Laemmli sample buffer and analyzed on $15 \%$ SDS-polyacrylamide gels. Supernatants from MSC-stimulated cells containing $250 \mu \mathrm{g}$ total protein were similarly incubated with heparin-Sepharose beads and analyzed for the amount of KGF protein. For TGF- $\alpha$ immunoblotting, the supernatants were concentrated ( $3 \mathrm{~K}$ mol wt cut off; concentrators from Flowgen, Lichfield, UK) and $350 \mu \mathrm{g}$ total protein was analyzed on $18 \%$ SDS-PAGE. For both growth factors, after electrophoresis and transfer to nitrocellulose membrane, nonspecific binding was blocked by incubating the membrane in $5 \%$ nonfat milk/PBS-T (PBS, $0.1 \%$ Tween 20) for $1 \mathrm{~h}$. After overnight incubation with the primary antibodies $(2 \mu \mathrm{g} / \mathrm{ml}$ goat anti-human KGF; $2 \mu \mathrm{g} / \mathrm{ml}$ goat anti-human TGF- $\alpha$; R\&D Systems), the membrane was washed three times with PBS-T, followed by incubation with horseradish peroxidase-conjugated rabbit anti-goat IgG (1:1,000; Dako Ltd.). The reaction was either developed using diaminobenzene as substrate or using the enhanced chemiluminescent method (Amersham International, Little Chalfont, UK).

Determination of the EGF receptor (EGFR) phosphorylation levels. To analyze EGFR protein content, 15 -wk fetal gut explants, cultured for $3 \mathrm{~d}$ in the presence of SEB, were homogenized in buffer $\mathrm{A}$ (10 mM Tris, $\mathrm{pH} 7.5$, containing 1\% [wt/vol] Triton X-100, $5 \mathrm{mM}$ EDTA, $1 \mathrm{mM}$ EGTA, $150 \mathrm{mM} \mathrm{NaCl}$, and protease inhibitors: $2 \mathrm{mM}$ sodium orthovanadate, $1 \mathrm{mM}$ PMSF, $10 \mu \mathrm{g} / \mathrm{ml}$ leupeptin, $10 \mu \mathrm{g} / \mathrm{ml}$ aprotinin, $10 \mu \mathrm{g} / \mathrm{ml}$ phenanthroline, and $1 \mathrm{mM} \mathrm{NaF}$ ). Lysates were clarified and protein content was determined as above. EGFR phosphorylation was determined by immunoprecipitating EGFR with rabbit anti-human EGFR antibody (Autogen Bioclear UK Ltd., Calne, UK) followed by immunoblotting using antiphosphotyrosine antibody (PY20; TCS Biologicals, Buckingham, UK). In brief, $1 \mu \mathrm{g}$ of anti-EGFR antibody was incubated with $1 \mathrm{mg}$ total lysate for $3 \mathrm{~h}$ at $4^{\circ} \mathrm{C}$. $100 \mu \mathrm{l}$ of protein A-Sepharose was added for the last hour of incubation. The beads were pelleted by centrifugation, washed three times in buffer A, and suspended in SDS sample loading buffer and boiled for $5 \mathrm{~min}$. The supernatant was subjected to $7.5 \%$ SDS-PAGE and immunoblotted. Nonspecific binding was blocked by overnight incubation with $5 \%(\mathrm{wt} / \mathrm{vol}) \mathrm{BSA}$ in TBS/T (Tris-buffered saline, $0.15 \%$ Tween 20 ). Incubation with primary antibody (antiphosphotyrosine, $0.1 \mu \mathrm{g} / \mathrm{ml}$ in $1 \% \mathrm{BSA} / \mathrm{TBS}-\mathrm{T}$ ) was for $2 \mathrm{~h}$ at room temperature followed by incubation with rabbit anti-mouse peroxidase-linked secondary antibody (1:20,000; Dako Ltd.). The blot was stripped and probed again with a second EGFR antibody (R1; Autogen Bioclear UK Ltd.) to quantify the amount of receptor. Detection was by an enhanced chemiluminescent method.

In situ hybridization. A 400-bp Xba1/Pst1 fragment of human 


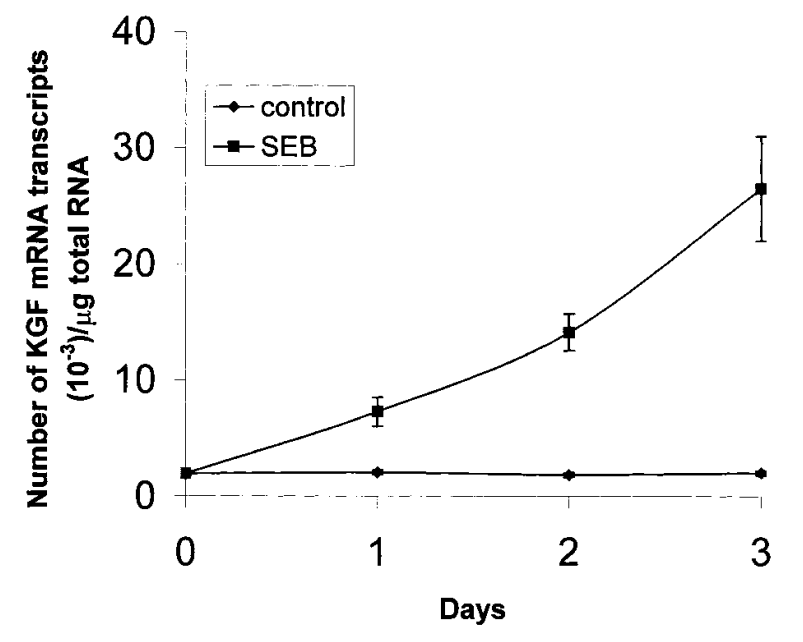

Figure 1. Number of KGF mRNA transcripts/ $\mu$ g total RNA in control and SEB-stimulated explants. The data for individual time points represent the mean \pm SEM of four different experiments. The tissue in all experiments was between 15 and 16 wk of gestation. Significant increase in KGF mRNA expression was observed on day 2, with greater increase on day 3 in SEB-stimulated explants compared with control tissue.
KGF was amplified by RT-PCR from a 16-wk fetal small intestine sample and subcloned into pGEM-3Zf(-) plasmid (Promega Corp., Madison, WI) at the corresponding restriction sites and the sequence of the probe confirmed by double-stranded di-deoxysequencing (Pharmacia, St. Albans, UK). After linearization of the plasmid with BamH1 or HindIII enzymes, single-stranded antisense and sense KGF riboprobes (sp act 0.8-1.7 $\times 10^{9}$ disintegrations/ $\mu \mathrm{g}$ RNA) were obtained using T7 or SP6 RNA polymerase and ${ }^{35} \mathrm{~S}-\mathrm{UTP}(800 \mathrm{Ci} /$ mmol; Amersham International). Paraffin-embedded sections of the explants were prepared after fixing the tissue in formalin-saline for $12-16 \mathrm{~h}$. Histological sections were treated as described by Senior and co-workers (33). In brief, $10^{6} \mathrm{cpm}$ of unhydrolyzed probe was hybridized overnight at $55^{\circ} \mathrm{C}$ to dewaxed sections permeabilized to proteinase $\mathrm{K}$. Posthybridization steps included several washes in $50 \%$ formamide buffer at $55^{\circ} \mathrm{C}$ to remove unhybridized probe, followed by RNase A treatment to digest single-stranded molecules, and extensive washing to remove cleaved fragments. The final two washes were at $65^{\circ} \mathrm{C}$ for $30 \mathrm{~min}$ in $0.5 \times \mathrm{SSC}(1 \times \mathrm{SSC}$ is $0.15 \mathrm{M} \mathrm{NaCl}, 0.015 \mathrm{M}$ sodium citrate). Slides were dehydrated, then dipped in Ilford K5 emulsion for autoradiography. As controls, parallel sections were hybridized to equal radioactivity amounts of antisense $\beta$-actin riboprobe.

\section{Results}

$T$ cell activation results in upregulation of KGF $m R N A$ and protein. Activation of the resident $\mathrm{T}$ cells in fetal small intes-
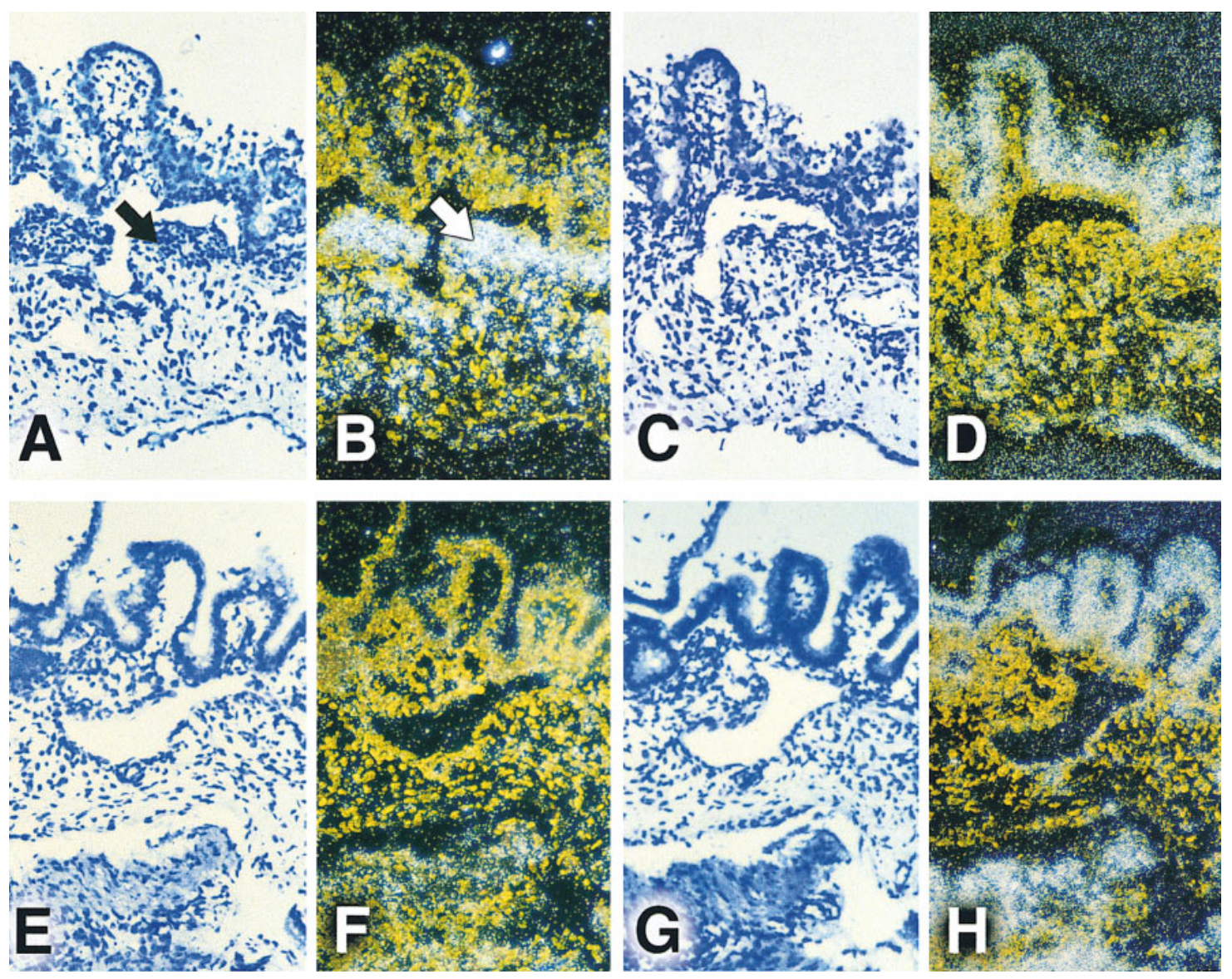

Figure 2. Detection of KGF mRNA expression by in situ hybridization (31-d exposure). $A$ and $B$ show light- and dark-field images of an SEBstimulated explant. $E$ and $F$ are similar images from control tissue. Intense positive signals for KGF $(B$, white arrow) were observed in the lamina propria with weaker, scattered signals in the deeper layers of the stimulated explants. In contrast, KGF mRNA transcripts were rarely detected in control tissue $(F)$. $C$ and $G$ correspond to light-field and $D$ and $H$ to dark-field for $\beta$-actin detection (10-d exposure) in SEB-stimulated and control tissue, respectively. $\times 50$. 
tine explants with SEB leads to crypt cell hyperplasia (32). Low levels of KGF mRNA expression were detected in day 0 explants; in control explants, the expression remained relatively unchanged over $72 \mathrm{~h}$ in culture (Fig. 1). In SEB-stimulated explants, the expression of KGF mRNA showed a 2-fold increase after $24 \mathrm{~h}$ and a 10 -fold increase at $72 \mathrm{~h}$.

To identify the cellular localization of the increase in KGF mRNA transcripts, in situ hybridization was performed on sections from control and SEB-stimulated explants (Fig. 2). After $3 \mathrm{~d}$ in culture, intense positive signals for KGF mRNA transcripts were observed in the lamina propria (Fig. $2 B$ ) of SEBstimulated tissue, with weaker scattered signals in the deeper layers. No positive signal was detected in the epithelial cells along the length of the villi or in the crypts. The close proximity of the increased KGF mRNA expression to the stem cells at the base of the crypt suggests paracrine effects of KGF on epithelial cell renewal on $\mathrm{T}$ cell activation. Weak, occasional signal was detected in the lamina propria of control explants (Fig. $2 F$ ). The $\beta$-actin antisense probe was included as a positive control, which as expected showed strong signal in most tissue compartments in both control and SEB-stimulated explants (Fig. 2, $D$ and $H$ ).

To determine whether increased expression of KGF mRNA correlates with elevated levels of KGF protein, culture supernatants were analyzed by Western blotting. A 26-28-kD doublet band corresponding to human KGF purified from M426 human conditioned media (34) was observed as early as day 1 in SEB-stimulated explants (Fig. 3) and the intensity of the immunoreactive KGF bands increased with time. Densitometric scanning revealed a 1.5-fold increase on day 2 and a 3.5fold increase in the amount of KGF protein on day 3 compared with day 1 . No KGF protein was detectable in control culture supernatants. The doublet pattern most likely reflects differential glycosylation or proteolysis of the mature glycosylated protein (34).

KGF production has been reported to be modulated in fibroblasts by cytokines $(35,36)$. Therefore, we examined the effect of proinflammatory cytokines on the production of KGF in primary fetal mucosal MSC. Direct addition of TNF- $\alpha$ (5 ng/ $\mathrm{ml})$ to confluent cultures led to a sixfold increase in KGF mRNA within $48 \mathrm{~h}$ (Fig. 4). However, IFN- $\gamma(300 \mathrm{U} / \mathrm{ml})$ or SEB $(10 \mu \mathrm{g} / \mathrm{ml})$ had no effect on KGF mRNA expression over the same incubation time. No effect was also observed in cells that were treated initially $(24 \mathrm{~h})$ with IFN- $\gamma$ to upregulate MHC-II expression (37) and then incubated with SEB for a further $48 \mathrm{~h}$. These data clearly show that SEB is not directly modulating the KGF mRNA expression in fibroblasts. These observations were further verified since KGF protein was only

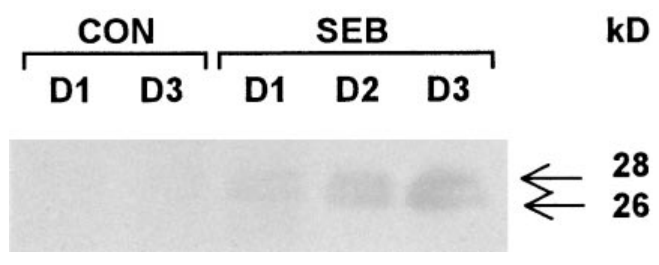

Figure 3. Western blot analysis for KGF in supernatants of control and SEB-stimulated explants after $72 \mathrm{~h}$ of incubation. No KGF protein was detectable in control tissue on days 1 and $3(D 1, D 3)$. In contrast, a progressive increase (from D1 to D3) in the KGF 26-28-kD protein doublet was observed in the SEB-stimulated explants.

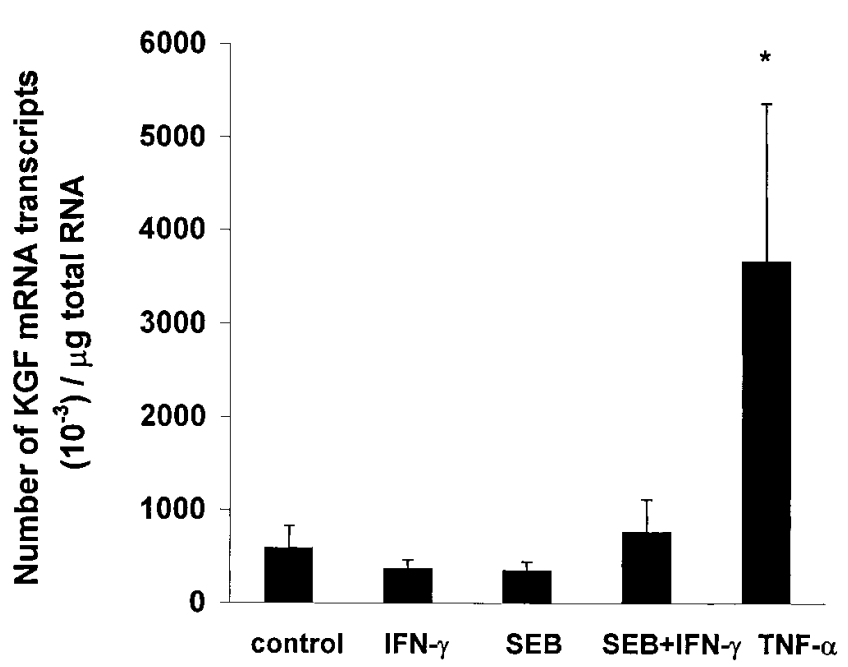

Figure 4. Number of KGF mRNA transcripts/ $\mu \mathrm{g}$ total RNA in cultured fetal mucosal MSC. Serum-starved $(24 \mathrm{~h})$ confluent cells were stimulated by IFN- $\gamma(300 \mathrm{U} / \mathrm{ml}), \operatorname{SEB}(10 \mu \mathrm{g} / \mathrm{ml}), \operatorname{IFN}-\gamma(300 \mathrm{U} / \mathrm{ml})+$ SEB $(10 \mu \mathrm{g} / \mathrm{ml})$, and with TNF- $\alpha(5 \mathrm{ng} / \mathrm{ml})$ for $48 \mathrm{~h}$. The data are mean \pm SEM of three experiments. Comparison of KGF mRNA expression among various groups was made using the Mann-Whitney $U$ test. Significant increase in KGF mRNA expression was found only in TNF- $\alpha$-stimulated cells $(P<0.05)$.

detectable in TNF- $\alpha$-stimulated culture supernatants of MSC cells (Fig. 5).

To determine if KGF plays a functional role in the increased epithelial cell proliferation observed in SEB-stimulated explants, we carried out inhibition studies using antiKGF antibody. SEB produced a large increase in the number of dividing cells in the crypts compared with unstimulated explants, an effect which was partially inhibited by anti-KGF antibody (Table I). In contrast, direct addition of exogenous recombinant KGF at low concentrations (0-20 ng/ml) had no effect on epithelial cell proliferation and a modest twofold increase was only observed at high doses $(500 \mathrm{ng} / \mathrm{ml})$ of the growth factor (Table I).

$T G F-\alpha$ in SEB-induced T cell activation. Earlier studies by Dlugosz and co-workers have implicated the TGF- $\alpha / E G F R$ pathway as an intermediary in signaling by the KGF/KGFR system (38). We explored this possibility by measuring the

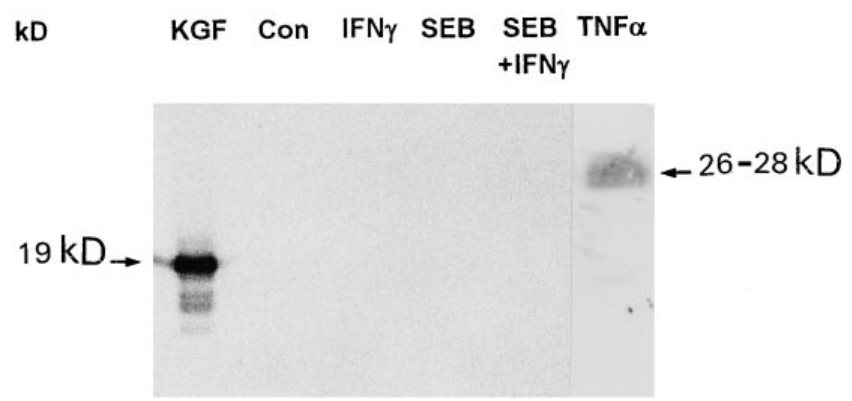

Figure 5. Upregulation of KGF protein by TNF- $\alpha$. Confluent cultures of fetal mucosal MSC were serum starved for $24 \mathrm{~h}$ and then treated with various cytokines, as in Fig. 4 . After 48 h, culture supernatants ( $250 \mu \mathrm{g}$ total protein) were collected and analyzed by Western blotting for KGF. Recombinant KGF (unglycosylated, 19-kD form) was included as a positive control. 
Table I. KGF and TGF- $\alpha$ Play a Role in Crypt Cell

Hyperplasia Observed after T Cell Activation

\begin{tabular}{lrrr}
\hline & \multicolumn{3}{c}{ Experiment } \\
\cline { 2 - 4 } & \multicolumn{1}{c}{1} & \multicolumn{1}{c}{2} \\
\hline Control & $5.8 \pm 0.4$ & $3.7 \pm 0.7$ & $4.8 \pm 0.7$ \\
SEB & $27.3 \pm 4.2$ & $32.7 \pm 5.8$ & $34 \pm 6.2$ \\
SEB + anti-KGF & $17.5 \pm 3.7$ & $21.7 \pm 4.6$ & $11.3 \pm 4.5$ \\
SEB + anti-TGF- $\alpha$ & $19.7 \pm 3.2$ & $22.8 \pm 6.7$ & $17.3 \pm 4.3$ \\
SEB + anti-IGF-1 & $28.4 \pm 4.8$ & $33.5 \pm 6.1$ & $29.5 \pm 5.7$ \\
Control + rTGF- $\alpha$ & $13.7 \pm 3.4$ & $7.5 \pm 1.2$ & $11.7 \pm 2.5$ \\
Control + rKGF & $10.2 \pm 1.9$ & $8.5 \pm 2.1$ & $8.2 \pm 1.2$ \\
& & & \\
\hline
\end{tabular}

Data of three individual experiments are represented as number of Ki67 cells/crypt (mean \pm SEM). A significant increase was observed in the number of proliferating cells in the crypts of SEB-stimulated explants compared with control tissue $(P<0.05)$. Addition of anti-KGF and anti-TGF- $\alpha$ antibodies $(10 \mu \mathrm{g} / \mathrm{ml})$ to SEB-stimulated explants showed a significant inhibition in the number of proliferating cells $(P<0.05)$. In contrast, anti-IGF-1 antibodies had no effect on the rate of epithelial cell renewal. The direct effect of the growth factor was studied by addition of $500 \mathrm{ng} / \mathrm{ml}$ of TGF- $\alpha$ and KGF to control explant culture supernatants. After $72 \mathrm{~h}$ of incubation, the explants were frozen and the number of proliferating cells/crypt was counted as above. Both KGF- and TGF$\alpha$-stimulated explants showed a significant increase in the number of proliferating cells compared to control $(P<0.05)$. Statistical analysis was by Mann-Whitney U test.

TGF- $\alpha$ protein content in SEB-stimulated culture supernatants (Fig. 6). TGF- $\alpha$ is known to exist in various precursor forms, ranging from 6 to $68 \mathrm{kD}$ (39). Although various size bands were detected by Western blotting, the strongest band seen was the $42-\mathrm{kD}$ isoform. As shown in Fig. 6, there is a marked increase in $\mathrm{TGF}-\alpha$ precursor proteins in the supernatants of SEB-stimulated explants. Induction of these various isoforms was observed as early as $24 \mathrm{~h}$ after SEB stimulation (data not shown). Interestingly, no mature form of TGF- $\alpha$ (5.6 $\mathrm{kD})$ was detectable by Western blotting techniques during the time course of these experiments $(72 \mathrm{~h})$. The biological effect of increased TGF- $\alpha$ proteins was studied by analyzing the EGFR and its phosphotyrosine content $(40,41)$. As shown in Fig. 7, immunoprecipitation of the EGFR from control and SEB-stimulated lysates showed the receptor to be phosphorylated only in the latter case, suggesting a role for this receptor signaling pathway in $\mathrm{T}$ cell-induced crypt cell hyperplasia. Further, inhibition studies with anti-TGF- $\alpha$ antibodies also resulted in a partial reduction in the number of proliferating epithelial cells in SEB-stimulated explants (Table I), suggesting like KGF, TGF- $\alpha$ also can influence the rate of epithelial cell renewal seen during $\mathrm{T}$ cell activation. Interestingly, direct addition of TGF- $\alpha$ at the same high dose as KGF (500 ng/ml) resulted in a similar twofold increase in epithelial cell proliferation (Table I).

To determine if KGF could indirectly affect the EGF/TGF- $\alpha$ receptor signaling pathway by modulating the levels of TGF- $\alpha$, control explant cultures were treated with recombinant KGF $(500 \mathrm{ng} / \mathrm{ml})$ for $72 \mathrm{~h}$ and corresponding supernatants were subjected to TGF- $\alpha$ immunoblotting. As shown in Fig. 6 there was an increase in the 42-, 38-, and 30-kD TGF- $\alpha$ precursor proteins in rKGF-treated explants, although the amount was

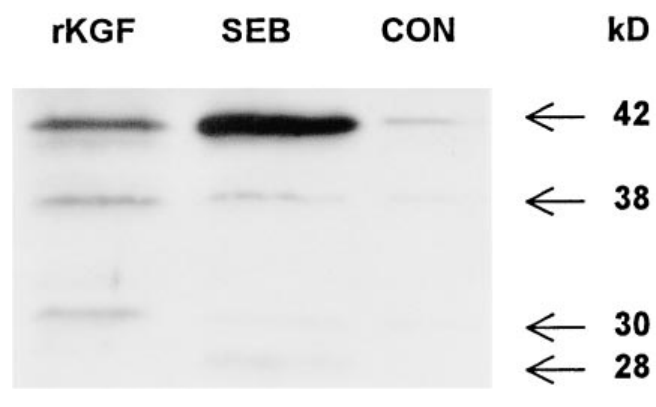

Figure 6. Upregulation of TGF- $\alpha$ precursor proteins in rKGF- and SEB-stimulated explant cultures. Fetal gut explants were cultured with $\mathrm{rKGF}(500 \mathrm{ng} / \mathrm{ml})$ or SEB $(10 \mu \mathrm{g} / \mathrm{ml})$ for $72 \mathrm{~h}$. Supernatants were collected and $350 \mu \mathrm{g}$ total concentrated protein was subjected to SDS-PAGE and subsequent immunoblotting for TGF- $\alpha$. Several bands $(28,30,38$, and $42 \mathrm{kD})$ were detected in SEB-stimulated explants $(S E B)$ compared with control $(C O N)$. In rKGF-stimulated explants $(r K G F), 30-, 38-$, and $42-\mathrm{kD}$ bands were observed. The different sizes represent various precursor forms of TGF- $\alpha$.

much less than that observed in SEB-treated explants. The 28$\mathrm{kD} \mathrm{TGF-} \alpha$ isoform was only observed in the latter case.

\section{Discussion}

This study establishes KGF and TGF- $\alpha$ as mediators of the increased epithelial cell proliferation seen after $\mathrm{T}$ cell activation in the gut. Even though these studies were carried out ex vivo using a bacterial superantigen to drive $\mathrm{T}$ cell activation, the morphological resemblance between the changes produced in the fetal gut and that seen in human diseases such as celiac disease $(42,43)$ and the fact that these studies were done in intact tissue, rather than extensively cultured cell lines, make the model relevant to our understanding of the molecular basis of human disease.

There was marked upregulation of KGF mRNA transcripts after $\mathrm{T}$ cell activation and this increase also correlates with increased protein expression. The source of this increased KGF mRNA expression and protein in the small intestine is not completely established. Earlier work by several groups has shown KGF to be synthesized and secreted by stromal cells and acts specifically on the epithelium of a wide variety of tissues (15, 44-46). Studies on tissue sections from patients with Crohn's disease and ulcerative colitis have shown MSC in the

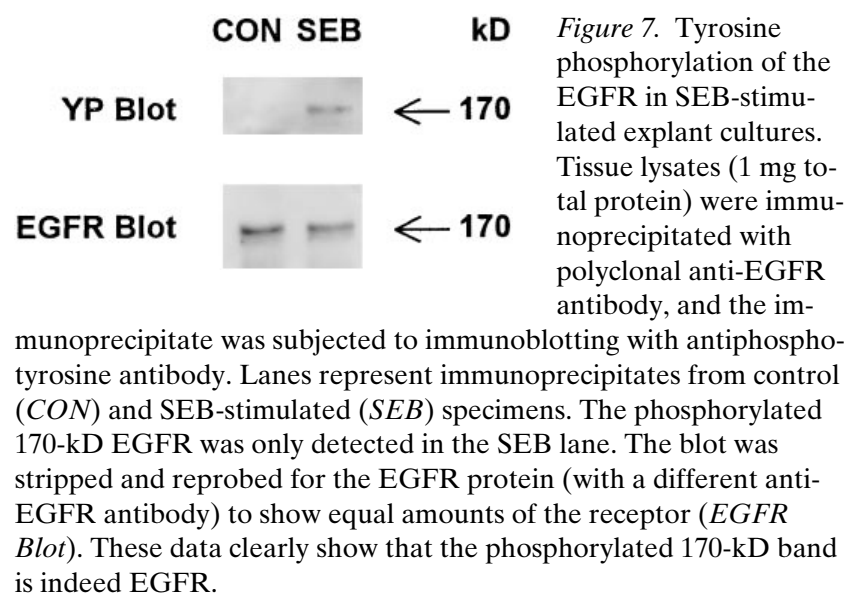


lamina propria to be the main source of KGF (20-22). However, Finch and colleagues suggest that KGF may also be made by $T$ cells (20). In mice it has been claimed that intraepithelial $\gamma \delta \mathrm{T}$ cells make KGF (47). However, this work has not been extended to humans. Based on our present in situ hybridization studies, it is difficult to resolve this issue, as positive signals for KGF mRNA were densely scattered throughout the lamina propria (Fig. 2 B), making it difficult to identify individual cell types involved in the synthesis of this growth factor. There is no evidence so far to implicate the involvement of any other immune cells (macrophage, monocyte, neutrophil) in the synthesis of KGF. Proinflammatory cytokines, such as IL-1 $\beta$, TNF- $\alpha$, and IFN- $\gamma$ which are released from T cells and macrophages during inflammation, are known to be potent inducers of KGF mRNA expression in fibroblasts from multiple sources $(35,36)$. In this study we show upregulation of KGF protein by cytokines in purified fetal mucosal MSC cultures confirming unequivocally that gut stromal cells can be a major source of KGF. We have also observed similar upregulation of KGF mRNA expression by cytokines (IL-1 $\beta$ and TNF- $\alpha$ ) in a colonic (CCD18Co) fibroblast cell line (Bajaj-Elliott, M., unpublished data).

To investigate if KGF has a direct effect on the epithelial cell proliferation seen after $\mathrm{T}$ cell activation with SEB, fetal small intestine explants were cocultured with a polyclonal neutralizing anti-KGF antibody. The reduction in the number of the dividing cells in the crypts of explants (Table I) shows clearly that $\mathrm{KGF}$ is an important mediator for epithelial cell proliferation in response to injury. Anti-TGF- $\alpha$ antibodies also showed a similar inhibitory effect on the number of Ki67-positive cells. Interestingly, in the same experimental system, anti-IGF-1 antibodies did not have any effect on the SEB-stimulated increase in epithelial cell renewal (Table I). Housley and co-workers have demonstrated the mitogenic effects of KGF for intestinal epithelial cells both in vitro and in vivo (19). Administration of exogenous KGF resulted in rapid (24-h) induction of epithelial cell proliferation. Morphological changes to noninflamed colon included an increase in colonic wet weight and colonic crypt depth and in the number of goblet cells per villi $(19,48)$. The mechanism(s) by which KGF can modulate epithelial cell renewal are still unclear. In our study, direct addition of the growth factor $(0-20 \mathrm{ng} / \mathrm{ml})$ to the explant culture system had no effect on epithelial cell proliferation; however, at higher doses $(500 \mathrm{ng} / \mathrm{ml})$ either KGF or TGF- $\alpha$ caused a twofold increase in epithelial cell proliferation compared with control tissue (Table I). Such a small increase in proliferation might reflect the maximum basal rate of epithelial cell renewal in control intact tissue and it is probable that only in response to injury, as observed in the SEB-stimulated explants, is this basal rate highly upregulated. Furthermore, the exact role of endogenous growth factors in such an experimental system is unknown. Similar observations have also been noted by Post and colleagues (49), where an effect of exogenous KGF on embryonic lung branching was only observed once the levels of endogenous growth factor had been reduced by antisense KGF oligonucleotides and further, similar high doses of growth factor were required to show an effect on proliferation. Furthermore, the addition of rKGF could only partially reverse the inhibitory effects of antisense KGF, suggesting even greater complexity to these cellular processes (49).

During the last several years, various EGFR ligands have been identified and found to be fundamental regulators of epi- thelial growth and differentiation $(50,51)$. A previous study by Dlugosz and co-workers implicated the TGF- $\alpha$ /EGFR receptor pathway as an intermediary in signaling through the KGFR (38). In our present study we have explored this possibility and have identified marked upregulation of various precursor forms of the TGF- $\alpha$ protein in SEB-stimulated explant supernatants. The mature form of the peptide was not detectable by Western blotting techniques even after $72 \mathrm{~h}$ of $\mathrm{T}$ cell activation. Recently, Hoffman and colleagues have also identified only the precursor forms of TGF- $\alpha$ in an acute model of experimental colitis in rats. They propose that the absence of the mature peptide may be due to its rapid removal from the lumen of the inflamed intestine (52). The absence of the mature protein in our ex vivo organ culture supernatants lends further support to their observations that the precursor forms of TGF- $\alpha$ may be the true ligands for the EGFR during episodes of inflammation. Further studies are required to define the exact role of these various proteins in modulating epithelial cell renewal via the EGFR signaling pathway. The issue of whether this increase in protein reflects changes in transcription, protein synthesis or in increased proteolysis of membrane-bound TGF- $\alpha$ was not addressed.

An increase in the phosphotyrosine content of the EGFR was observed after $72 \mathrm{~h}$, thus showing directly that this receptor system is activated in the SEB-stimulated explants. Studies by Dlugosz and colleagues (38) and our present data suggest one possible mechanism by which the KGF/KGFR pathway may be involved in activation of the EGFR system, i.e., by modulating the levels of the various TGF- $\alpha$ precursor proteins. The complex molecular cross-talk between the KGF/KGFR and the TGF- $\alpha / E G F R$ systems requires further investigation. In noninflamed tissue, TGF- $\alpha$ has been localized to the mature enterocytes at the tips of the villi where it is likely to exert its role in epithelial restitution $(25,53)$. In contrast, in inflamed intestine, the expression of TGF- $\alpha$ was found in epithelial cells of the upper crypt region (25), where it is more likely to influence the rate of epithelial cell renewal. Our present in situ hybridization study on fetal tissue shows increased KGF mRNA expression around the bottom of the crypt. A recent study from our laboratory has also shown similar distribution of KGF mRNA expression in adult inflammatory bowel disease tissue (22), further validating the choice of the ex vivo model in the study of human disease. This closer proximity of KGF and TGF- $\alpha$ observed during inflammation suggests greater cross-talk between the two pathways, which may reflect communication between the rate of stem cell renewal in the crypt and the rate of transit of the immature enterocyte to the villi tip. The activation of the TGF- $\alpha$ /EGFR pathway has also been shown to lead to tyrosine phosphorylation of the c-met receptor, even in the absence of its ligand (54), suggesting a novel mechanism by which various growth factor receptor pathways may modulate the final rate of epithelial cell renewal.

Recent studies on the KGF and TGF- $\alpha$ knockout mice are increasing our understanding of the processes involved in tissue repair after injury. Interestingly, the KGF knockout and double knockout (KGF and TGF- $\alpha$ ) mice show no impairment in their wound healing abilities (55). Tissues where epithelialmesenchymal cell interactions are known to be important for development were found to be morphologically/histologically normal. These observations may reflect genetic redundancy, because a dominant negative mutant of the KGFR expressed in the basal keratinocyte layer blocks cell proliferation of the 
wound margin and delays reepithelization (56). These observations suggest that acidic FGF which has affinity for the FGFR2 receptor (57) or an as yet unidentified ligand might also play a role in modulating crypt cell division through the KGF/FGFR2 receptor signaling pathway.

Recent studies by Egger and colleagues (58) have shown increased susceptibility of TGF- $\alpha$ knockout mice to dextran sulfate-induced colitis and amelioration of the colonic injury by exogenous application of the growth factor, suggesting TGF- $\alpha$ as a mediator of protection and/or healing in the colon. It would be interesting to study the $\mathrm{KGF} / \mathrm{KGFR}$ receptor pathway in these mice to further elucidate the extent of overlap between the two signaling pathways and their exact role in epithelial cell proliferation.

Several studies have also implicated the extracellular matrix to play a role in modulating the effects of growth factors. Affinity of KGF for heparin and heparan sulfate proteoglycans (59) and its ability to stimulate high plasminogen activator and MMP-10 expression (60) may also affect epithelial cell renewal indirectly by enhancing the rate of transit of the undifferentiated epithelial stem cell from the base of the crypt to the more differentiated form at the tip of the villi. Further studies are required to define the exact role and interactions between multiple parallel growth factor-dependent pathways that regulate epithelial cell proliferation in the crypt during inflammation.

\section{Acknowledgments}

The authors would like to thank the Wellcome Trust, CICRA and the Imperial Cancer Research Fund for financial support.

\section{References}

1. Ciacci, C., Y.R. Mahida, A. Dignass, M. Koizumi, and D. Podolsky. 1993. Functional interleukin 2 receptors on intestinal epithelial cells. J. Clin. Invest. 92:527-532.

2. McGee, D.W., and S.J. Vitkus. 1996. IL-4 enhances IEC-6 intestinal epithelial cell proliferation yet has no effect on IL-6 secretion. Clin. Exp. Immunol. 105:274-277.

3. Reinecker, H.C., R.P. MacDermott, S. Mirau, A. Dignass, and D.K. Podolsky. 1996. Intestinal epithelial cells both express and respond to interleukin 15. Gastroenterology. 111:1706-1713.

4. Kaiser, G.C., and D.B. Polk. 1997. Tumor necrosis factor $\alpha$ regulates proliferation in a mouse intestinal cell line. Gastroenterology. 112:1231-1240.

5. Kilshaw, P.J. 1985. Induction of class II MHC antigens in cultured epithelial cells from rat gut. Int. Arch. Allergy Appl. Immunol. 78:326-328.

6. Garside, P., A.K. Hutton, A. Severn, F.Y. Liew, and A.M. Mowat. 1992. Nitric oxide mediates intestinal pathology in graft-vs-host disease. Eur. J. Immunol. 22:2141-2145.

7. Mowat, A.M., A.K. Hutton, P. Garside, and M. Steel. 1993. A role for interleukin-1 alpha in immunologically mediated intestinal pathology. Immunology. 80:110-115.

8. Mowat, A.M., and M.B. Widmer. 1995. A role for IL-4 in immunologically mediated enteropathy. Clin. Exp. Immunol. 99:65-69.

9. Garside, P., C. Bunce, R.C. Tomlinson, B.L. Nichols, and A.M. Mowat. 1993. Analysis of enteropathy induced by tumour necrosis factor alpha. Cytokine. 5:24-30.

10. Lollini, P.L., A. D’Errico, C.D. Giovanni, L. Landuzzi, F. Frabetti, G. Nicoletti, F. Cavallo, M. Giovarelli, W.F. Grigioni, and P. Nanni. 1995. Systemic effects of cytokines released by gene-transduced tumor cells: marked hyperplasia induced in small bowel by $\gamma$-interferon transfectants through host lymphocytes. Int. J. Cancer. 61:425-430.

11. Kurokowa, M., K. Lynch, and D.K. Podolsky. 1987. Effects of growth factors on intestinal epithelial cell line: transforming growth factor beta inhibits proliferation and stimulates differentiation. Biochem. Biophys. Res. Commun. 142:775-784

12. Drucker, D.J., P. Erlich, S.L. Asa, and P.L. Brubaker. 1996. Induction of intestinal epithelial proliferation by glucagon-like peptide 2. Proc. Natl. Acad. Sci. USA. 93:7911-7916.
13. Ohneda, K., M.H. Ulshen, C.R. Fuller, A.J. D'ercole, and P.K. Lund. 1997. Enhanced growth of small bowel in transgenic mice expressing human insulin-like growth factor 1. Gastroenterology. 112:444-454.

14. Playford, R.J., R. Boulton, M.A. Ghatei, S.R. Bloom, N.A. Wright, and R.A. Goodlad. 1996. Comparison of the effects of transforming growth factor alpha and the epidermal growth factor on gastrointestinal proliferation and hormone release. Digestion. 57:362-367.

15. Finch, P.W., J.S. Rubin, T. Miki, D. Ron, and S.A. Aaronson. 1989. Human KGF is FGF-related with properties of a paracrine effector of epithelial cell growth. Science. 245:752-755.

16. Werner, S., K.G. Peters, M.T. Longaker, F. Fuller-Pace, M.J. Banda, and L.T. Williams. 1992. Large induction of keratinocyte growth factor expression in the dermis during wound healing. Proc. Natl. Acad. Sci. USA. 89:68966900 .

17. Staiano-Coico, L., J.G. Krueger, J.S. Rubin, S. D'limi, V.P. Vallat, L. Valentino, T. Fahey III, G. Kingston, M.R. Madden, M. Mathwich, et al. 1993. Human keratinocyte growth factor effects in porcine model of epidermal wound healing. J. Exp. Med. 178:865-878.

18. Yi, E.S., S.T. Williams, H. Lee, D.M. Malicki, E.M. Chin, J. Tarpley, and T.R. Ulich. 1996. Keratinocyte growth factor ameliorates radiation and bleomycin-induced lung injury and mortality. Am. J. Pathol. 149:1963-1970.

19. Housley, R.M., C.F. Morris, W. Boyle, B. Ring, R. Biltz, J.E. Tarpley, S.L. Aukerman, P.L. Devine, R.H. Whitehead, and G.F. Pierce. 1994. Keratinocyte growth factor induces proliferation of hepatocytes and epithelial cells throughout the rat gastrointestinal tract. J. Clin. Invest. 94:1764-1777.

20. Finch, P.W., V. Pricolo, A. Wu, and S.D. Finkelstein. 1996. Increased expression of keratinocyte growth factor messenger RNA associated with inflammatory bowel disease. Gastroenterology. 110:441-451.

21. Brauchle, M., M. Madlener, A.D. Wagner, K. Angermayer, U. Lauer, P.H. Hofschneider, M. Gregor, and S. Werner. 1996. Keratinocyte growth factor is highly overexpressed in inflammatory bowel disease. Am. J. Pathol. 149: 521-529.

22. Bajaj-Elliott, M., E.J. Breese, R. Poulsom, P.D. Fairclough, and T.T. MacDonald. 1997. Keratinocyte growth factor in inflammatory bowel disease: increased mRNA transcripts in ulcerative colitis compared with Crohn's disease in biopsies and isolated mucosal fibroblasts. Am. J. Pathol. 151:1469-1476.

23. Barnard, J.A., W.H. Polk, H.L. Moses, and R.J. Coffey. 1991. Production of transforming growth factor-alpha by normal rat small intestine. Am. J. Physiol. 261:C994-C1000.

24. Thomas, D.M., M.M. Nasim, W.Y. Gullick, and M.R. Alison. 1992. Immunoreactivity of transforming growth factor-alpha in the normal gastrointestinal tract. Gut. 33:628-631.

25. Dignass, A.U., J.L. Stow, and M.W. Babyatsky. 1996. Acute epithelial injury in the rat small intestine in vivo is associated with expanded expression of transforming growth factor- $\alpha$ and $\beta$. Gut. 38:687-693.

26. Dignass, A.U., and D.K. Podolsky. 1993. Cytokine modulation of intestinal epithelial cell restitution: central role for transforming growth factor- $\beta$. Gastroenterology. 105:1323-1332.

27. Dignass, A.U., S. Tsunekawa, and D.K. Podolsky. 1994. Fibroblast growth factors modulate intestinal epithelial cell growth and migration. Gastroenterology. 106:1254-1262.

28. Lionetti, P., E.J. Breese, J. Spencer, C.P. Breagger, S. Murch, J. Taylor, and T.T. MacDonald. 1993. Activation of V $\beta 3+\mathrm{T}$ cells and tissue damage in human small intestine induced by the bacterial superantigen, Staphylococcus aureus enterotoxin. Eur. J. Immunol. 23:664-668.

29. Autrup, H., L.A. Barrett, F.E. Jackson, M.L. Jesudason, G. Stoner, P. Phelps, B.F. Trump, and C.C. Harris. 1978. Explant culture of human colon. Gastroenterology. 74:1248-1257.

30. Pender, S.L.F., S.P. Tickle, A.J.P. Docherty, D. Howie, N.C. Wathen, and T.T. MacDonald. 1997. A p55 TNF receptor immunoadhesion prevents T cell mediated intestinal injury by inhibiting matrix metalloproteinase production. J. Immunol. 158:1582-1590.

31. Issacson, P.G., and D.H. Wright. 1983. Immunocytochemistry of lymphoreticular tumours. In Immunocytochemistry: Practical Applications in Pathology and Biology. J.M. Polak and S. van Noorden, editors. John Wright \& Sons, Bristol. 249 pp.

32. MacDonald, T.T., and J. Spencer. 1988. Evidence that activated mucosal $\mathrm{T}$ cells play a role in the pathogenesis of enteropathy in human small intestine. J. Exp. Med. 167:1341-1349.

33. Senior, P.V., D.R. Critchley, F. Beck, R.A. Walker, and J.M. Varley. 1988. The localisation of laminin mRNA and protein in the post-implantation embryo and placenta of the mouse: an in situ hybridisation and immunocytochemical study. Development. 104:431-446.

34. Finch, P.W., G.R. Cunha, J.S. Rubin, J. Wong, and D. Ron. 1995. Pattern of keratinocyte growth factor and the keratinocyte growth factor receptor during mouse fetal development suggests a role in mediating morphogenetic mesenchymal-epithelial interactions. Dev. Dynamics. 203:223-240.

35. Brauchle, M., K. Angermeyer, G. Hüber, and S. Werner. 1994. Large induction of keratinocyte growth factor expression by serum growth factors and proinflammatory cytokines in cultured fibroblasts. Oncogene. 9:3199-3204.

36. Chedid, M., J.S. Rubin, K.G. Csaky, and S.A. Aaronson. 1994. Regulation of keratinocyte growth factor gene expression by interleukin 1. J. Biol. 
Chem. 269:10753-10757.

37. Ousuky, R., R.J. Dorio, Y.K. Arora, S.J. Ryan, and S.M. Walker. 1997. $\mathrm{MHC}$ class II positive retinal pigment epithelial cells can function as antigenpresenting cells for microbial superantigen. Recept. Signal Trans. 5:43-50.

38. Dlugosz, A.A., C. Cheng, M.F. Denning, P.J. Dempsey, R.J. Coffey, and S.H. Yuspa. 1994. Keratinocyte growth factor receptor ligands induce transforming growth factor- $\alpha$ expression and activate the epidermal growth factor receptor signalling pathway in cultured epidermal keratinocytes. Cell Growth. Differ. 5:1283-1292.

39. Elizalde, P.V., and E.H. Charreau. 1990. Alpha-transforming growth factor-like activities and bifunctional regulators of cell growth in human malignant neoplasms. Cancer Invest. 8:365-374.

40. Downward, J., P.J. Parker, and M.D. Waterfield. 1984. Autophosphorylation sites on the epidermal growth factor receptor. Nature. 311:483-485.

41. Li, N., J. Schlessinger, and B. Margolis. 1994. Autophosphorylation mutants of the epidermal growth factor receptor signal through auxiliary mechanisms involving SH2 domains. Oncogene. 9:3457-3465.

42. Shiner, M. 1957. Histopathological changes in the malabsorption syndrome. J. Mt. Sinai Hospital. 24:273-285.

43. Rubin, C.E., L.L. Brandburg, P.C. Philips, and C.T. Taylor, Jr. 1958. Intestinal similarities between celiac disease and idiopathic sprue. J. Clin. Invest. 58:927-928.

44. Alarid, E.T., J.S. Rubin, P. Young, M. Chedid, D. Ron, S.A. Aaronson, and G.R. Cunha. 1994. Keratinocyte growth factor functions in epithelial induction during vesicle development. Proc. Natl. Acad. Sci. USA. 91:1074-1078.

45. Koji, T., M. Chedid, J.S. Rubin, O.D. Sliaden, K.G. Csaky, S.A. Aaronson, and R.M. Brenner. 1994. Progesterone-dependent expression of keratinocyte growth factor mRNA in stromal cells of the primate endometrium: keratinocyte growth factor as a progestomedin. J. Cell Biol. 125:393-401.

46. Guo, L., Q.-C. Yu, and E. Fuchs. 1993. Targeting expression of keratinocyte growth factor to keratinocytes elicits striking changes in epithelial differentiation in transgenic mice. EMBO (Eur. Mol. Biol. Organ.) J. 12:973-986.

47. Boismenu, R., and W.L. Havran. 1994. Modulation of epithelial cell growth by intraepithelial $\gamma \delta \mathrm{T}$ cells. Science. 266:1253-1255.

48. Zeeh, J.M., F. Procaccino, P. Hoffmann, S.L. Aukerman, J.A. McRoberts, S. Soltani, G.F. Pierce, J. Lakshmanan, D. Lacey, and V.E. Eysselein. 1996. Keratinocyte growth factor ameliorates mucosal injury in an experimental model of colitis in rats. Gastroenterology. 110:1077-1083.

49. Post, M., P. Souza, J. Liu, I. Tseu, J. Wang, M. Kulizewski, and A.K.
Tanswell. 1996. Keratinocyte growth factor and its receptor are involved in regulating lung branching. Development. 122:3107-3115.

50. Ullrich, A., and J. Schlessinger. 1990. Signal transduction by receptors with tyrosine kinase activity. Cell. 61:203-212.

51. Miettinen, P.J., J.E. Berger, J. Meneses, Y. Phung, R.A. Pederson, Z Werb, and R. Derynck. 1995. Epithelial immaturity and multiorgan failure in mice lacking epidermal growth factor receptor. Nature. 376:337-341.

52. Hoffmann, P., J.M. Zeeh, J. Lakshmanan, V.S. Wu, F. Procaccino, M. Reinshagen, J.A. McRoberts, and V.E. Eysselein. 1997. Increased expression of transforming growth factor $\alpha$ precursors in acute experimental colitis in rats. Gut. 41:195-202.

53. Babyatsky, M.W., G. Rossiter, and D.K. Podolsky. 1996. Expression of TGF-alpha and beta in colonic mucosa in inflammatory bowel disease. Gastroenterology. 110:975-984

54. Presnell, S.C., D.B. Stolz, W.M. Mars, M. Jo, G.K. Michalopoulos, and S.C. Strom. 1997. Modifications of the hepatocyte growth factor/c-met pathway by constitutive expression of transforming growth factor-alpha in rat liver epithelial cells. Mol. Carcinog. 18:244-255.

55. Guo, L., G. Degenstein, and E. Fuchs. 1996. Keratinocyte growth factor is required for hair development and not wound healing. Genes Dev. 10:165175

56. Werner, S., H. Smola, X. Liao, M.T. Longaker, T. Kreig, P.H. Hofschneider, and L.T. Williams. 1994. The function of KGF in morphogenesis of epithelium and re-epithelization. Science. 266:819-822.

57. Bottaro, D.P., J.S. Rubin, D. Ron, P.W. Fitch, C. Florio, and S.A Aaronson. 1990. Characterization of the receptor for keratinocyte growth fac tor. J. Biol. Chem. 265:12767-12770.

58. Egger, B., F. Procaccino, J. Lakshmanan, M. Reinshagen, P. Hoffmann, A. Patel, W. Reuben, S. Gnanakkan, L. Liu, L. Barajas, and V. Eysselein. 1997. Mice lacking transforming growth factor $\alpha$ have an increased susceptibility to dextran sulfate-induced colitis. Gastroenterology. 133:825-832.

59. Friedl, A., Z. Chang, A. Tierney, and A.C. Rapraeger. 1997. Differential binding of fibroblast growth factor-2 and -7 to basement membrane heparan sulfate. Am. J. Pathol. 150:1443-1455.

60. Madlener, M., C. Mauch, W.M. Brauchle, W.C. Parks, and S. Werner. 1996. Regulation of the expression of stromelysin-2 by growth factors in keratinocytes: implications for normal and impaired wound healing. Biochem. J. 320: $659-664$. 